\title{
Appendiceal Carcinoma pNO TNM Finding v7
}

National Cancer Institute

\section{Source}

National Cancer Institute. Appendiceal Carcinoma pNO TNM Finding v7. NCI Thesaurus. Code $C 89906$.

Appendiceal carcinoma without regional lymph node metastasis. (from AJCC 7th Ed.) 